\title{
The Existence and the Effect of Sex Tourism Habitus in Bandungan, Central Java, Indonesia
}

\author{
Argyo Demartoto ${ }^{1}$ \\ ${ }^{1}$ Department of Sociology, Faculty of Social and Political Sciences, Sebelas Maret University, Surakarta, \\ Indonesia \\ Correspondence: Argyo Demartoto, Department of Sociology, Faculty of Social and Political Sciences, Sebelas \\ Maret University, Ir. Sutami Street 36 A Kentingan, Surakarta 57121, Indonesia. Tel: 62-271-637-277. E-mail: \\ argyodemartoto@ymail.com
}

\author{
Received: July 24, 2013 Accepted: September 3, 2013 Online Published: October 29, 2013 \\ doi:10.5539/ass.v9n15p93 URL: http://dx.doi.org/ass.v9n15p93
}

\begin{abstract}
This research is a qualitative research with case study approach aimed to find out the existence and the effect of sex tourism habitus in Bandungan, Central Java, Indonesia.The data source used in this research was primary data obtained directly from commercial sexual workers, coordinator of commercial sexual workers (procurer or pimp); inn guest escort (mediator) consisting of hotel employees, tukang ojek, tukang sate; as well as apparatus, people surrounding and Local Government. The secondary data used to support the primary data was previous studies relevant to sex tourism, news in printed media, and documentation taken during the research. Techniques of collecting data were in-depth interview, direct observation and documentation. The data analysis was an interactive model of analysis. The prostitutes in Bandungan were called tukang sate (sate seller). Generally they come from outside local areas such as Kendal, Rembang, Semarang, Surakarta, Wonosobo, and so on. Some of them operate openly but some other disguisedly as karaoke guides, beauty salon employees, and massage center employees. They did not hawk themselves directly, but through agent (mediator) connecting them to the tourists. The mediators were hotel employees, tukang ojek and tukang sate. Most sexual tourists came from out of Bandungan. All of them serve as the agent in sex tourism habitus in Bandungan. The large number of hotels, inns, lodgings, and entertainment centers such as karaoke automatically opened the job opportunity for the surrounding people so that they accept their existence. The prostitutes paid sufficiently attention to health problem by routinely having their health examined. When some of them developed Sexual Infectious Disease, they would be referred to Ambarawa Local General Hospital and prohibited from catering the guest except they had been cured.
\end{abstract}

Keywords: prostitutes, agent, habitus, sex tourism

\section{Introduction}

The tourism concept expands for its sector. The slogan "sun, sea and sex" is the form of such expansion, in which sex becomes one of tourist attraction in addition to natural scenery and cultural tradition in tropical countries. Sun, sea and sex make the tropical countries interesting not only because of its natural rich. But, is it a positive progress because prostitution becomes the job opportunity increasing the state's foreign exchange or is it a deterioration of humanity aspect (Samarasuriya, 1997; Ryan \& Hall, 2001; Cabezas, 2009; Kibicho, 2009; Brents et al., 2010).

Indonesia as a tropical country has a big attraction because of abundant sun and sea, even some of which becomes the famous tourist objects such as Kuta Beach in Bali Island, Senggigi in Lombok, Pangandaran in West Java, Toba Lake in North Sumatera, Bromo Mountain in East Java, Tangkuban Perahu in West Java, and more. Such the attractions are getting larger because of combined attractive nature and fragile socio-economic condition. Many people need job, but the job opportunity is limited, so that sexual industry sector becomes alternative that can be the source of income.

Bandungan is the mountains tourist object existing in Bandungan Village, Bandungan Sub district, Semarang Regency. This area is well-known for its cool weather, beautiful scenery thereby many villas, resorts, hotels and inns are established there. In Bandungan, there are many things to attract the tourists' interest, either domestic or foreign: Gedongsongo Temple, nine temples with stone stair connecting one temple to other, the location of the 
nine temples is not equally high; the first one is at the lowest, then the second, and so on. The temple complex lies about $10 \mathrm{~km}$ from Bandungan. In the front yard of Gedongsongo Temple complex there is camping location and hot water bathing the source of which is in the left of third temple. In Bandungan Rail Service Company's House, there is a place for children's playing, swimming pool, tennis court, fishing pool, hotel, and various types of meal. In Bandungan, there are also famous soybean milk and tofu plants, fresh vegetable and fruit market with low price.

It is well-established that tourism development in Bandungan has positive and negative effects on the people surrounding. The construction of villa, resort, hotel, inn, and entertainment center such as karaoke directly absorb many workers from the people surrounding and it increase their income. But, it also exerts negative effect such as prostitution activity and prostitute emergence to cater the tourist's sexual need. For that reason, the existence and the effect of sex tourism habitus in Bandungan is interested to study. This research explored the sex tourism habitus particularly the one in Bandungan, including the history of its establishment and the performer network or agent of sex tourism habitus in Bandungan, community's response and social-economic and health effect of sex tourism habitus in Bandungan.

\section{Literature Review}

\subsection{Theory of Practice}

A very determinant factor of sex tourism operation in Bandungan is the ownership of same habitus (habit) between the performers of activity. Durkheim's argument about collective consciousness is really helpful to understand the symptoms. Collective consciousness is outside individual. Having been aspirated, gotten information, been developed and established, collective consciousness is formulated and stored in the corresponding society's language. Then, it can be inherited to the next generation. When the society generation originally aspirating and developing the collective consciousness dies, there will be a new generation that can aspirate it. Collective consciousness can also be considered as superior to individual one because it has the power of organizing behavior and becoming the guideline for the members of society (Durkheim, 1964).

Bourdieu formulates habitus concept as a sociological and philosophical analysis on human being behavior. In this sense, habitus is the social values perceived by human being and created through value socialization process lasting for a long time, thereby precipitated into thinking way and behavior pattern residing inside human being. An individual's habitus is so strong that affects his physical body. Habitus that has been planted so strong and precipitates into physical behavior is called Hexis. Meanwhile, capital is the asset enabling us to get opportunities in life. There are many types of capital: intellectual (education), economic (money) and cultural (background \& network). Capital can be obtained, if people have appropriate habit in his life. Meanwhile, arena is the special room existing within the society. There is a variety of arenas, such as education, business, artist, and politic. If someone wants to be successful in an arena, she/he should have appropriate habitus and capital (Bourdieu, 1977; Harker, 1984; Harker et al., 1990; Bourdieu \& Wacquant, 1992).

Generally, theory of practice concerns the relationship between individual and collective processes, symbolic and material or economic power. On the other hand, individual practice apparently has limitation and it forms through logically cultural structure. However, these individuals can also be seen as the agent having power (reinforce) or can resist the larger structure enclosing it. Meanwhile, social cultural life is a product of both of them, namely social structure and individual agent. Such condition relation repetition, in theory of practice focuses on how domination is revived through culture or symbolic thins, such as economical politics and material powers. The rationale of practice theory thinking is inequality and disempowerment. Practical theory puts individual action back onto its main position (center stage), as the personal agency contributing to the activity (Bourdieu, 1977, 1991; Harker, 1984). In this context, the beautiful young sexy woman coming from other areas or, according to Bourdieu's practice theory assumption the woman from original area habitus then becomes the commercial sexual worker and contributes to sex tourism habitus.

Foucault considers that there has been modern repression on sexuality related to capitalism development. In this case, it is the actual sexuality, natural instinct existing within human being and can activate human being's desire. But, is the instinct so dominant inside human being (Foucault, 1980). What Foucault says about sexual repression and capitalism will likely have relationship with women fate in modern world. Beyond that, capitalism has reduced sexuality only as "sex" and commodity providing economic surplus. In the sense, sexuality has been identical with physical shape or body attracting consumer's attention to enjoy it, and that is woman. Even "sexuality shadow" in woman is confirmed by printed and electronic media produced by modernity itself (Cabezas, 2009; Brents et al., 2010). Although prostitution is considered as pathological behavior criticized widely by the society as well as a variety regulation used widely to narrow their moving 
space, this activity increasingly develops either qualitatively or quantitatively.

\subsection{Causing Factor, Type and Prostitution Network}

Some studies have been conducted on prostitution. Meyer (1988) and Truong (1992) studied the prostitution activity in South East Asia, particularly in Thailand, from social-cultural factors. Boonchalaksi and Guest (1994) saw prostitution in Thailand as service industry. Despite denial and morally condemnation, prostitution or commercial sex is the service business with very high economic value.

Viewed from its history, the prostitution problem is the one known since many centuries ago on earth. The development of prostitution is because of many aspects and is very complicated. There are two factors leading to increasing number of sexual worker: supply and demand. Supply is related to poorly educated and high poverty among the women and the society as can be seen from their very high proportion in nearly all of prostitution types. Demand aspect is the increasingly good welfare and ability of the men to buy sexual service (Jones et al., 1995; Ryan \& Hall, 2001; Kibicho, 2009).

Prostitution will not automatically disappear in the presence of social economic improvement because it is related to demand, in addition to injustice and exploitation. Meanwhile, a variety of prostitution practice itself is frequently highly affected by certain cultural context, so that the scope of sex tourism area actually becomes increasingly complicated to be targeted systematically (Murray, 1991; Jones et al., 1995; Ryan \& Hall, 2001).

Prostitution activity can be divided into several types and classes: street, disguised, amateur prostitutions, localization (brothel), and callgirl. Non-transparent prostitution is perhaps larger in number than the transparent one. Prostitution within the society has indeed developed in so complicated and symptomatic way in various forms, that some of them can be identified easily and some others difficultly (Brouwer, 1970; Soedjono, 1977; Darwin, 1995; Ryan \& Hall, 2001).

In sexual industry, there are two categories: service (prostitution, striptease \& telephone sex) and product (pornography \& sex aids). One of industry highly affected by globalization and tourism development recently is sexual industry combining the oldest and the newest professions in the world. In internet, there is website World Sex Guide with very detailed information about prostitution, escort agencies and night club in hundred cities throughout world (Spillane, 2002; Brents et al., 2010). The widespread sexual industry in some countries including Indonesia leads many children to be force to become commercial sexual worker (prostitutes) (Boonchalaksi \& Guest, 1994; Archavanitkul, 2000). Around Surakarta city of Central Java, Indonesia, many girls coming from poor and broken home families becoming street children even becomes the prostituted children. They become the victim of child commercial sex exploitation (Demartoto, 2012). End Child Prostitution, Pornography \& Trafficking (ECPAT, 2000) estimates that millions children are entrapped into dark valley and sexual industry, and are frequently exploited to cater tourist.

Prostitution involves many parties and has very wide network, even crossing state borders. There are at least four parties involved in this 'business': protector of commercial sexual worker, or usually called "pimp" or procurer. This procurer is usually a man, but it may be a women. The mediator is the one facilitating this business that connects the prospect prostitute to the procurer or to the customers directly. And marketing division is the one specially paid to develop this business, including searching for the prospect prostitutes in various places, moving/delivering/selling the prostitutes to various places, either nationally or internationally (Ryan \& Hall, 2001; Cabezas, 2009; Kibicho, 2009).

\subsection{Tourism, Prostitution, and Sexual Infectious Disease}

Tourism can likely be called the main source of prostitution industry development, but that both of them are interrelated systematically, no scholar refutes it, including sex tourism (Clift \& Carter (Eds.), 2000; Demartoto (Ed.), 2009).Sex tourism can be defined that an individual's objective of leaving his residence is to enjoy sexual intercourse. If it is done with his spouse it is not a problem, but the connotation contained behind the sex tourism is the combination between tour and prostitution. Sex tourism involves so many parties and people that it even becomes a wide structured network (Sousa, 1994; Ryan \& Hall, 2001; Cabezas, 2009).

Truong (1992), based on his study on sex tourism in Thailand mentions that there are four main tendencies in considering sexual industry problem. Firstly, bio-social perspective argues that sexual behavioral pattern is purely because of biological impulse, in which the man is considered as having higher sexual impulse than the woman does. As such, the man is more expressive and aggressive in sexuality issue; therefore historically, the man dominates the woman. Secondly, socio-cultural perspective considers that sexual behavior as well as all of its regulations is the product of interaction between sexual impulse and socio-cultural system, in which the man is the determinant of regulation. It means that the woman sexuality is the result of patriarchal construction. 
Thirdly, historical perspective emphasizes its analysis on the role of economic relationship in creating norms and sexual relationship. Fourthly, "sexual discourse diversity" perspective emphasizes on a variety of probabilities in linking the clusters of idea about sex, its regulation and practices to wider social change, with various implication. In this article, the writer attempts to reveal the relationship of woman as the commercial sexual workers to the man as consumer (sexual tourist) contributing to sex tourism habitus. McNay (1999) stated that it serves as the gendered habitus in which this framework is relevant to the Bourdieu's concept stating that there is an interrelationship between structural, symbolic and class status aspects.

Sexual tourists can be divided into 4 categories. The first is those coming in sexual tourist group that has been organized in their origin country. So, sexual tourist has been prepared by the organizer. The second is those coming independently and freely, with sex as the main purpose. The third is those coming to enjoy "paradise vacation", the one with special program not obtained at home, including sexual program, whether with man, woman or children. The fourth is those who as soon as they arrive at the tourist destination directly look for sexual intercourse with commercial sex workers. In addition, in all of this categories there should be differentiated between routine and occasional tourist (Susanto, 2002).

The relationship of consumer (tourist) to commercial sexual worker can be the "power" to "need" relationship. Firstly, the tourist has a 'power' because he has money. The commercial sexual worker has 'need' for money to support his life with family. Secondly, the relationship of consumer (tourist) to commercial sexual worker is a very imbalanced one; one is very strong, and another is very weak. Thirdly, their relationship is interdependency relationship. It can also apply to the tourist (Muroi \& Sasaki, 1997, p. 181; Nasikun, 2002). As we know, the very strong social-cultural patriarchal construction in Indonesia puts the man superior to the woman, the man has more power, is more dominant than the woman particularly because the man has many money (Nilan \& Demartoto, 2012).

Prostitution is not only low quality of moral problem, but also wide HIV/AIDS transmission, whereas the attempt to mitigate the transmission risk is difficult because the low knowledge and awareness among the prostitutes and the low knowledge among the society. The health level of performer in sex industry in the present and in the future is closely related to Sexual Infectious Disease including HIV/AIDS. No condom used leads to quick growth of HIV/AIDS patients among prostitutes, consumers, and other people (Jones et al., 1995).

\section{Research Methods}

This research is a qualitative research with case study, the one conducted intensively and in-depth to a case in certain social environment (Yin, 1981; Denzin \& Lincoln (Eds.), 2000). The case study selected was intrinsic case study meaning to study the case specifically. In line with the objective of research to find out the existence and the effect of sex tourism habitus in Bandungan, Central Java, Indonesia.

The data source used in this research was primary data obtained directly from commercial sexual workers, coordinator of commercial sexual workers (procurer or pimp); inn guest escort (mediator) consisting of hotel employees, tukang ojek, tukang sate; as well as apparatus, people surrounding and Local Government. The secondary data used to support the primary data was previous studies relevant to sex tourism, news in printed media, and documentation taken during the research. In this research, techniques of collecting data used were in-depth interview, direct observation and documentation. The author employed an interactive analysis method from Miles and Huberman (1994) through research procedure and stages including data collection, data reduction, data display and drawing and verifying conclusions.

\section{Result and Discussion}

\subsection{Dynamics and Performer Network or Agent Supporting the Existence of Sex Tourism Habitus in Bandungan.}

Bandungan is the part of Bandungan Sub district's area of Semarang Regency. The altitude of Semarang Regency area as $318 \mathrm{~m}-1.450 \mathrm{~m}$. The area with lowest altitude is Ungaran Sub district at $318 \mathrm{~m}$ and the highest one is Getasan Sub district at $1.450 \mathrm{~m}$, with weather temperature of $23-26^{\circ}$ Celcius and weather humidity around $80-81 \%$. The average altitude is $607 \mathrm{~m}$, the average rainfall rate is $1.979 \mathrm{~mm}$ and the number of rainy days is 104 Such the condition is particularly affected by geographical location of Semarang Regency surrounded by mountains and river so that the tour prioritized is the resorting tour offering cool weather and mountains scenery as the main attractions.

Bandungan Sub district is one of 19 sub-districts located in Semarang Regency. Bandungan Sub district alone is $43.28 \mathrm{~km}^{2}$ wide, with 53.520 populations, and population density of 1104 people $/ \mathrm{km}$. The populations, on the average, are vegetable farmers (BPS, 2011). The Bandungan tourist object can be reached by driving for 1 hour from the southern part of Semarang or about 20 minutes from Ungaran, or about 15 minutes from Ambarawa 
through mountains route.

According to the story existing within the society, the origin of Bandungan name departed from a couple of Sanggem husband and wife obtaining divine inspiration to look for well in the slope of Ungaran Mountain, the one the water of which flows like the river in order to have offspring. Having found the well, they have many children, then they got divine inspiration again to dam up the well to prevent it from causing disaster to the kampongs below; as a consequence, there will no longer source and finally the well is closed with gong (The Javanese traditional music, a percussion instrument consisting of a metal plate that is a struck with a softheaded drumstick). The village is eventually known as Bandungan (bendungan = dam). The grave of Kyai Sanggem lies behind the Bandungan Sub district Office. According to the native people of Bandungan, Bandungan area has been famous for its sex tourism since 1980s. The hotel in Bandungan area is very cheap, ranging from 30 to 50 thousands rupiahs only, thus it attracts many tourists from outside area. But foreign tourist is very rarely found.

The existence of sex tourism in Bandungan is supported by the performers involved within it. The commercial sexual worker, in local term is called "Tukang Sate"; commercial sexual worker operating disguisedly (karaoke guides, beauty salon employees, massage center employees); procurer (pimp/prostitutes coordinator); inn guest escort (mediator: hotel employees, tukang ojek, tukang sate) and tourists. The commercial sexual worker in Bandungan tourist area is known as 'tukang sate'. Just like the tukang (sellers) of rabbit sate, this kind of tukang sate also serves flesh 'sticking" despite different flesh and 'sticking' objective. So don't agree in hurry with "Sate Mas, hangat (Sate Brother, warm") offering if you visit Bandungan. If the seller does not bring charcoal and fan to keep the flame flaring up, never expect the rabbit sate meal because he is surely vending the prostitutes. Most sexual workers come from outside town. Some of them came alone and joined other prostitutes or followed their friends' successful track to be sexual worker. Some commercial sexual workers in Bandungan operate openly and disguisedly by working as karaoke guides or employees of massage center. The prostitution location in Bandungan lies in strategic place, among other, in the alley near Citra Dewi I, Citra Dewi II, and Citra Dewi III hotels. There are many karaoke sites, beauty salon, and massage center there.

Sexual commercial workers enlisted in Bandungan tourist area is 175 in number, about 100 massage center and spa employees. There are about 8 melati class hotel and 18 spa centers in Bandungan tourist object changing its function into commercial sexual workers' boarding house and karaoke guides. According to the Coordinator of Kelompok Sadar Wisata (Tourism Awareness Group) of Bandungan Sub district, the hotel management, massage center and spa are forced to change their business function into boarding house and shelter, because the business competition between hotel managements is getting tighter and as the solution to avoid operational damage so far.

Generally, the sexual commercial workers is vending directly in the edges of street. They have a pimp governing and protecting sexual commercial workers. Nevertheless, some other are vending directly to the customers. Commercial sexual workers working as karaoke guide is more structured. They are "displayed" in the glass box like aquarium thereby facilitating the customers to select whom they will ask to have sexual intercourse. The role of mediator, hotel employees, tukang ojek, tukang sate, is to confront the commercial sexual employees with consumer (tourist). Such the condition occurs recalling that the consumers (tourists) can select the commercial sexual workers incorrectly because the one they choose is perhaps the local one who is not commercial sexual worker (prostitute). In addition, the mediator can guide the consumer to see the commercial sexual workers who reside in certain places or houses coordinated by procurer (prostitute coordinator).

In addition to commercial sexual workers, karaoke center owner, beauty salon, massage center, and procurer (pimp), there are society leader, food and beverage stall owner, government apparatus collecting 'tax', massager, parking officer, and tukang ojek contributing to the existence of prostitution activity in Bandungan. The relationship between them is a sufficiently strong collectivity. Such the collectivity is established in a variety of social, economic and cultural relationship. So the sex tourism network in Bandungan has been structured.

The tourists visiting the tourist destination in Bandungan who will undertake sex tourism also conducts sex tourism network or habitus. The government apparatus related to the sex tourism habitus in Bandungan tourist area includes Tourism Office, Local Income Office (related to tax retribution), Health Office, Social Office or other offices.

\subsection{The Social, Economic, and Health Effect of Sex Tourism Habitus in Bandungan}

Tourism sector aims to increase foreign exchange revenue, business and job opportunities. Bandungan as the tourist destination existing around Ungaran area has positive and negative effects. The positive effect includes increased income for the local area and populations surrounding, created job opportunity, and increase life quality of the local society surrounding tourist destination. Meanwhile, the negative effect includes bad reputation of Bandungan from formerly known as natural tourist object to sex tourism. 
Bandungan sex tourism attracts many visitors from outside town because it is supported with typical circumstance of mountains, very beautiful scenery, cool weather, the presence of Gedongsongo temple, cheap melati class of hotel, and cheap market making many tourists are interested to come back to Bandungan.

Since 1980s, Bandungan is known as sex tourism. It has become the public secrete for the Bandungan society either inside or outside Bandungan. The government and law enforcers are as if silent so that the raid is rarely undertaken to the prostitutes. The members of society never protest the presence of sex tourism, and are only submitted to it, because it is sufficiently profitable. It indicates that the members of society support indirectly the sex tourism. Even they offer the prostitutes to the tourists, because many of them are tukang ojek, parking officer, hotel employees, and work in karaoke center and serve as the procurer or mediator all at once, become the tourist escort to the hotel room. From that, the members of society with such the profession get tips from the prostitutes. However, some Bandungan people sometimes still feel uncomfortable with the clothes worn by the prostitutes because it can harm the children's moral.

The existence of sex tourism in Bandungan highly affects the economic development of Bandungan people. Many people have double profession as tukang ojek (motorcycle driver), procurer or pimp (recruiter and escort) of sexual workers to the consumer. From that, the people get substantial tips, because they get 30-50 thousands rupiahs for delivering one sexual commercial worker to the consumer. According to the people surrounding, in addition to becoming procurer or pimp (recruiter and escort), many people surrounding build boarding houses for prostitutes, because most prostitutes come from outside Bandungan areas such as Semarang, Surakarta, Kendal, Rembang, Wonosobo, and etcetera. In addition to boarding houses, many melati hotels and karaoke centers existing in Bandungan is the job opportunity for the people to become hotel karaoke, parking officer, karaoke server, cleaning service, and etcetera.

The existence of sex tourism has social effect. From the religion perspective, the commercial sexual worker existing in Bandungan is prohibited and resisted firmly but its existence cannot be denied, moreover Bandungan tourism object is visited by increasingly large number of tourists, including those who want to express his sexual passion. Prostitutes and tourists who want to enjoy the prostitute's service can be said as having bad moral. They no longer care about religion clearly prohibits the prostitution activity. They as if do not care about the effect they will assume, they only transcend temporary secular pleasure.

In health aspect, Bandungan sex tourism can be said as sufficiently safe. According to information of mas $Y$ 's who works as the escort of Inn Guest. Every prostitute should have her health examined in Puskesmas (Public Health Center) to find out whether or not he suffers from Sexual Infectious Disease. The examination is conducted routinely in Tuesday and Thursday. When some prostitutes are infected by sexual infectious disease, they will be referred to Ambarawa Local General Hospital in order to receive further treatment. In Ambarawa Local General Hospital, they will receive treatment and be monitored for their treatment in order not to cater the guest as long as they had not been cured from their disease. HIV is the disease frequently found in sexual worker, but according to mas $\mathrm{Y}$, he never meets any prostitutes suffering from HIV. The diseases ever existing in Bandungan sex tourism area include syphilis and suppurated urinating.

There are three strategies taken by AIDS Overcoming Commission of Semarang Regency in the attempt of overcoming HIV/AIDS distribution. Firstly, the prevention of HIV/AIDS transmission is conducted through socialization and campaign about condom use among the prostitutes surrounding Bandungan tour object. In addition, the Prevention Mother to Child Transmission program is also held to prevent the mother's disease from infecting the children. Secondly, Sexual Infectious Disease and HIV/AIDS case overcoming through health service to people with HIV/AIDS and thirdly, the rehabilitation for people with HIV/AIDS by opening social, economic, and health access.

The public participation is very desirable including never stigmatizing or discriminating people with HIV/AIDS. Particularly to the management of hotel and entertainment centers such as karaoke, it is appealed to develop information corner about HIV/AIDS danger. It is intended as the socialization and information distribution to support the attempts of overcoming HIV/AIDS.

\subsection{Discussion}

Sex tourism habitus in Bandungan remains to exist until today. It is due to the existence of performers or agents supporting it. The agents serving to support the activity included commercial sexual workers, coordinator of commercial sexual workers (procurer or pimp); inn guest escort (mediator) consisting of hotel employees, tukang ojek (commercial motorcycle driver), tukang sate (sate seller); as well as apparatus, people surrounding and Local Government. The performers or agents have asset, either socially, culturally and symbolically. The strength of habitus originates from the established network between performers or agents of sex tourism habitus, 
and either internal or external parties of sex tourism habitus.

Bandungan sex tourism network has a structured and sufficiently wide network. The prostitutes not only come from Bandungan, but from several cities in Indonesia. Work mechanism or system is also tidy enough and well-organized. The prostitutes have their own origin local habitus when they have not participated in that activity. Encouraged by various reasons, particularly economic factor, they are engaged in sex tourism habitus. Having been engaged, those who refuse will exit from sex tourism habitus, meaning that they do not accept the sex tourism habitus. Those who accept sex tourism habit will be involved continuously in the activity that in turn will occupy the new structure in their role in sex tourism habitus. They unconsciously contribute to maintaining the existence of sustainability of sex tourism habitus in sex tourism habitus performer network in Bandungan. As they participate in that activity, some other actors also become the performer just like her. On the other hand, some sex tourism habitus performers also crochet postmodernism habitus intended to be realized by means of earning money in sex tourism habitus.

Considering Bourdieu framework (1991) with language analogy used to see the existence of sex tourism habitus internally, by understanding various activities of sex tourism habitus performers. Bourdieu thought's contains habitus concept as one of factors supporting the existence of sex tourism habitus. This concept is used as the attempt of understanding the components existing in sex tourism habitus consisting of object structure, practices and performers. Habitus is the medium interconnecting the object structure and its operating activity.

Sex tourism habitus in Bandungan still exists up to now because there are personals engaged in such the activity, for example the presence of those becoming prostitutes, tourists (consumer), agents or mediators, and apparatuses. Sex tourism habit is flexible to agent or mediator, and commercial sexual workers. When the commercial sexual workers are preferred by consumer (tourist), they may only ask for permission to agent or mediator. So do when they want to move to other room, house, or outside Bandungan. The performers create a network to keep their sex tourism habitus existing. The recent development in Bandungan indicates the telecommunication technology use in that activity, for example using cellular phone, internet and transportation vehicle.

The ever changing performers of sex tourism habitus in Bandungan is the form of sex tourism habitus existence. The commercial sexual workers newly living there adapt quickly recalling the presence of "new merchandise" concept. The "new merchandise" commercial sexual workers always get many consumers, meaning get much money. Recalling that it is money that they earn, the will live there happily. Such the process will change the local habitus of their origin area into the sex tourism habitus because of enjoyment being the sex tourism habitus performers in Bandungan. Some commercial sexual workers have boyfriends and married with the local people. Their involvement with villagers, among other in special celebration activity and other social life makes them just like living at their own house. In Bandungan, the characteristics of villager are still very strong. Generally, the native people prioritize more the kinship trait and system, collectivity, and consider the new comer, in this case, commercial sexual worker (prostitute) who lives in their boarding house, as the member of family. This phenomenon remains to be found particularly in rural areas of Central Java (Demartoto, 2013).

Recalling that Bandungan has been relatively long the sex tourism habitus, many native people are engaged within it. The involvement and socialization occurring in the original population can be seen by renting out house, becoming the procurer (prostitute coordinator), hotel employees, tukang ojek, and parking officer. Even the native people then become the prostitutes. Bandungan people involved in sex tourism habitus leads to proliferation of prostitute within the society in whether the legal localization of prostitutes, illegal one, or disguised prostitution practices in stalls, inns, hotels, karaoke place, massage house, and steam bath. It can result in amoral society situation and condition that legalizes sexual intercourse out of marriage. Thus, the amoral behavior is as if cultivated within the society. The individuals becoming the members of society can deteriorate in their moral and ethical values. For that reason, non-sexual minded situation and condition of society should be kept from the perception that sexual intercourse is an ordinary thing and can be undertaken whenever, wherever, and with whomever.

In addition, there are a number of populations refusing sex tourism habitus. Such the refusal is reflected from the movement of some families to other village or other places, although they have house in Bandungan. The population living in prostitution environment indeed encounters a variety of dilemmatic things. On the one hand, they realize that their environment is not healthy particularly for their children. On the other hand, they cannot leave from that place. Several families even can earn living by selling the facilities in prostitution activity.

Sex tourism habitus in Bandungan will remain to exist because there is an attempt of keeping the sex tourism habitus existence and sustainability in Bandungan. In the mechanism of Bandungan sex tourism habitus, those 
getting benefit are hotel owner, room owner, and procurer. They indirectly act as the agents that establish a collective awareness of sex tourism that will result in the existence of Bandungan sex tourism habitus.

The simplest sex tourism habitus actually occurs only between prostitute and the tourist (consumer), but in Bandungan it is manipulated by the presence of hotel employees, tukang ojek, tukang sate, and procurer. The income obtained by the prostitutes even sometimes is less than they do. Meanwhile, the work volume performed by the prostitutes is higher. The prostitutes, procurers, hotel employees, tukang ojek, tukang sate, apparatus, and tourist (consumer) existing in Bandungan sex tourism habitus, have different awareness from each other referring to one collective awareness that having sexual intercourse out of marriage by giving return is something allowed. This collective awareness is the manifestation of the performers' sex tourism habitus. Collective awareness is very different from another referring to the norms existing within the society. Collective awareness the performers of sex tourism habitus have is not always acceptable to be applied to other society, recalling that they have different collective awareness.

Collective awareness consisting of sex tourism habitus unconsciously socialized into the individual newly involved in sex tourism habitus, eventually reproducing sex tourism habitus. Otherwise, individual that has been involved can exit from the sex tourism habitus if their mind has an awareness of creating habitus referring to the norms enacted in the public. Generally, the performers of sex tourism habitus leave from the system very difficult, recalling that the habitus cannot be change in short time.

At least, there are three factors determining the sustainable mechanism of sex tourism habitus: weak policy, economic need, and sex tourism habitus. Basically, there is no article in Penal Code (KUHP) prohibiting prostitution activity, the one prohibited is pimp or procurer practice. If later there are some actions limiting the activity, the sex tourism habitus activity keeps running, recalling that nowadays modern communication media are used to connect to the fellow performers of sex tourism activity.

The fulfillment of economic needs, particularly for the prostitutes also supports the sex tour habitus sustainability. Both factors are supported by habitus allowing sexual intercourse out of marriage. Another determinant of sex tourism habitus sustainability is the place for that activity. Recalling Bandungan has been relatively long used for sex tourism habitus, the individuals living there have been socialized with the sex tourism habitus. The equally important factor supporting the existence of sex tourism activity is the presence of areas supplying the prostitutes such as Kendal, Wonosobo, Semarang and etc.

The attitude of people surrounding Bandungan to sex tourism habitus in their area making the sex tourism habitus remains to exist is not different from that of people around the prostitution occurring in other part of world. The presence of places providing biological fulfillment service in Bandungan is more determined by the attitude of population accepting it. Their attitude is more affected by their assessment on the status of woman. The economic life development in Bandungan put the women onto economical order. Another factor making the sex tourism habitus remains to exist, is the wide distribution of sex tourism habitus within the society there, makes the sex tourism habitus an important economic activity. Such the condition can occur because of stronger sex tourism cultural bond compared with its moral bond.

\section{Conclusion and Recommendation}

\subsection{Conclusion}

The sex tourism habitus in Bandungan has been well-distributed. It is a dispositional system occurring for a long time and functioning as generative basis for the objectively structured and integrated practices.

Commercial sexual workers (prostitutes) in Bandungan are known as tukang sate. Some of them operate openly and some other disguisedly as karaoke guides, beauty salon employees, massage center employees. Prostitutes do not vend them directly, but though agent (mediator) connecting them to the consumer (tourist). These agents are hotel employees, tukang ojek, and tukang sate. The prostitutes in Bandungan generally come from outside towns such as Kendal, Rembang, Semarang, Surakarta, Wonosobo, and so on. The sexual tourists come from out of Bandungan and even from Jakarta.

The existence of prostitutes surrounding Bandungan tourist destination area exerts both positive and negative effect on the society. Various job opportunities are created, from hotel, karaoke center, ojek, stall as well as HP counter. On the other hand, the negative effect includes Sexual Infectious Disease and direct psychological effect on the society.

The prostitutes in Bandungan pay sufficiently attention to their health problem. Every Tuesday and Thursday they have their health examined routinely in Puskesmas and when some of them suffer from Sexual Infectious Disease will be referred to Ambarawa Local General Hospital and prohibited from catering the guests until they 
are cured actually.

\subsection{Recommendation}

The development of tourism has implication to scale and organization of sexual service and composition of labor market relating to prostitution. For that reason, the government and tourist industry should take into account and consider the prostitution issue relating to tourism. However, the attention may not focus on the regulations based on incorrect, incomplete information, and not thinking long term consequence. In addition to focusing on human right, the consumer accepting sexual service, the government should focus more on the welfare of local people encountering negative consequence of this tourism development.

Information Communication and Education about health problem, particularly Sexual Infectious Disease and HIV/AIDS should be intended to the prostitutes (prostitute centered) but it should also get large portion for community (the community centered), particularly the man (male centered). Because with adequate knowledge, the consumer man (sexual tourist) will keep them and family away from Sexual Infectious Disease.

The community should be empowered by not stigmatizing or by refusing the presence of commercial sex workers who have decided to go back to the society.

\section{References}

Archavanitkul, K. (2000). Combating the Traficking in Children and their Exploitation in Prostitution and Other Intolerable Forms of Child Labour in Mekong Basin Countries. Retrieved from http://www.seameo.org/vi/combat/index.html

Boonchalaksi, W., \& Guest, P. (1994). Prostitution in Thailand. Institute for Population and Social Research. Bangkok: Mahidol University.

Bourdieu, P. (1977). Out line of A Theory of Practice. United Kingdom: Cambridge University Press. http://dx.doi.org/10.1017/CBO9780511812507

Bourdieu, P. (1991). Language and Symbolic Power. Edited and With An Introduction by John B. Thompson. Cambridge: Harvard University Press.

Bourdieu, P., \& Wacquant, L. J. D. (1992). An Invitation to Reflexive Sociology. Oxford: Polity Press.

Brents, B. G., Jackson, C. A., \& Hausbeck, K. (2010). The State of Sex: Tourism, Sex, and Sin in The New American Heartland. New York: Routledge.

Brouwer, M. A. W. (1970). Antara Senyum dan Menangis. Jakarta: PT Gramedia.

Cabezas, A. L. (2009). Economies Of Desire Sex and Tourism in Cuba and the Dominican Republic. Philadelphia: Temple University Press.

Clift, S., \& Carter, S. (Eds.). (2000). Tourism and Sex: Culture, Commerce and Coercion. London: Pinter.

Darwin, M. (1995). Overview: Kesehatan Reproduksi. Yogyakarta: Pusat Penelitian Kependudukan dan Kebijakan Universitas Gadjah Mada.

Demartoto, A. (2012). Need-Based Street Children Management in Surakarta City of Central Java Province of Indonesia. Asian Social Science, 8(11), 107-118. http://dx.doi.org/10.5539/ass.v8n11p107

Demartoto, A. (2013). The Role of Family in Bringing the Elderly's Well-Being into Reality in Rural Areas of Central Java, Indonesia. Asian Social Science, 9(5), 191-202. http://dx.doi.org/10.5539/ass.v9n5p191

Demartoto, A. (Ed.). (2009). Pembangunan Pariwisata Berbasis Masyarakat. Surakarta: Sebelas Maret University Press.

Denzin, N. K., \& Lincoln, Y. S. (Eds.). (2000). Handbook of Qualitative Research. California: Sage Publications Inc.

Durkheim, E. (1964). The Division of Labour in Society. New York: The Free Press.

ECPAT. (2000). End Child Prostitution, Pornography \& Trafficking. Retrieved from http://www.scfa.asn.au/porn.html

Foucault, M. (1980). The History Of Sexuality: An Introduction (1). New York: Vintage Random House.

Harker, R. K. (1984). Reproduction, Habitus, and Education. British Journal of Sociology of Education, 5(2), 117-127. http://dx.doi.org/10.1080/0142569840050202

Harker, R., Mahar, C., \& Wilkes, C. (1990). An Introduction To The Work of Pierre Bourdieu: The Practice of 
Theory. London: Palgrave Macmillan Limited.

Jones et al. (1995). Prostitution in Indonesia. ANU. Research School of Social Science No. 52. Canberra: The Australian National University.

Kibicho, W. (2009). Sex Tourism in Africa: Kenya's Booming Industry. England: Ashgate Publishing Limited.

McNay, L. (1999). Gender, Habitus and the Field: Pierre Bourdieu and Limits of Reflexivity. Theory, Culture \& Society, 16(1), 95-117. Retrieved from http://dx.doi.org/ 10.1177/026327699016001007

Meyer, W. (1988). Beyond the Mask: Toward a Transdisciplinary Approach of Selected Social Problems Related to the Evolution and Context of International Tourism in Thailand. Saarbrucken Fort Lauderdale: Verlag Breitenbach Publisher.

Miles, M. B., \& Huberman, A. M. (1994). Qualitative Data Analysis: An Expanded Source Book (2nd ed.). California: Sage Publications Inc.

Muroi, H., \& Sasaki, N. (1997). Tourism and Prostitution in Japan". In M. T. Sinclair (Ed.), Gender, Work, and Tourism. London and New York: Routledge.

Murray, A. J. (1991). Pedagang Jalanan dan Pelacur Jakarta, Sebuah Kajian Antropologi Sosial. Jakarta: LP3ES.

Nasikun. (2002). Kecenderungan Baru Perkembangan Wisata Seks di Asia: Suatu Penjelasan Sosiologis. In Proceeding Seminar Nasional "Wisata Seks Dalam Industri Pariwisata: Peluang Atau Ancaman". Yogyakarta: Pusat Pengembangan Dan Pelatihan Pariwisata Universitas Sanata Dharma, Ecumenical Coalition On Third World Tourism serta Komisi Migran dan Perantau KWI.

Nilan, P., \& Demartoto, A. (2012). Patriarchal Residues in Indonesia: Respect Accorded Senior Men by Junior Men. European Journal of Social Sciences, 31(2), 279-293.

Ryan, C., \& Hall, C. M. (2001). Sex Tourism Marginal People and Liminalities. London and New York: Routledge.

Samarasuriya, S. (1997). Sun-Surf-Sex Tourism. Samar, 7. Retrieved from http://www.samarmagazine.org/archive/articles/82

Soedjono. (1977). Pelacuran, Ditinjau dari Segi Hukum dan Kenyataan dalam Masyarakat. Bandung: PT Karya Nusantara.

Sousa, D. (1994). Sex Tourism in Asia. ACSJC Occasional Paper No. 20. North Blackburn. Victoria: Collins Dove.

Spillane, J. J. (2002). Etika Bisnis dan Industri Seks Sebagai Kegagalan Pasar Bebas. In Proceeding Seminar Nasional "Wisata Seks Dalam Industri Pariwisata: Peluang Atau Ancaman". Yogyakarta: Pusat Pengembangan Dan Pelatihan Pariwisata Universitas Sanata Dharma, Ecumenical Coalition On Third World Tourism serta Komisi Migran dan Perantau KWI.

Statistik, B. P. (2011). Kabupaten Semarang Dalam Angka Tahun 2011. Kabupaten Semarang: Badan Pusat Statistik.

Susanto, H. (2002). Wisata Seks: Tinjauan Moral. In Proceeding Seminar Nasional "Wisata Seks Dalam Industri Pariwisata: Peluang Atau Ancaman". Yogyakarta: Pusat Pengembangan Dan Pelatihan Pariwisata Universitas Sanata Dharma, Ecumenical Coalition On Third World Tourism serta Komisi Migran dan Perantau KWI.

Truong, T. D. (1992). Seks, Uang dan Kekuasaan: Pariwisata dan Pelacuran di Asia Tenggara. Jakarta: LP3ES.

Yin, R. K. (1981, March). The Case Study Crisis: Some Answers. Administrative Science Quarterly, 26, 58-65. http://dx.doi.org/10.2307/2392599

\section{Copyrights}

Copyright for this article is retained by the author(s), with first publication rights granted to the journal.

This is an open-access article distributed under the terms and conditions of the Creative Commons Attribution license (http://creativecommons.org/licenses/by/3.0/). 